\section{Dragica Stojanovic ${ }^{1}$}

Biljana Ilic $^{2}$

University of John Naisbitt, Belgrade,

Faculty of Management, Zaječar, Serbia

Jelena Moračanin

Belgrade Business School, Belgrade, Serbia
SCIENTIFIC REVIEW ARTICLE

DOI:10.5937/ekonomika1703077S

Received: May, 12, 2017

Accepted: Jun, 09, 2017

\title{
SUSTAINABLE DEVELOPMENT OF LOCAL COMMUNITIES IN SERBIA AND FDI
}

\begin{abstract}
Foreign direct investment as the most common form of international capital movements are very important factors in the development of each economy. Given the fact its characteristics in terms of the impact on long-term economic development, foreign direct investment offer the possibility of achieving goals of sustainable development. In the terms that the effects of foreign capital does not manifest in the same way at all levels in the host country, the paper gives the importance of foreign direct investment for strength the capacity of local communities in achieving the goals of sustainable development. The point of the paper is to show movement of foreign direct investments in municipalities and cities in Serbia and to provide useful recommendations for improving the business climate to attract foreign direct investment in local communities. Starting from the fact that the needs of local communities in Serbia to attract foreign direct investment are big, at the end of the paper it is given that investment location are the most important determinants of the host country by foreign investors when making investment decisions
\end{abstract}

Key words: Foreign direct investment (FDI), sustainable development, local communities, determinations of FDI

JEL classification: Q00

\section{ОДРЖИВИ РАЗВОЈ ЛОКАЛНИХ ЗАЈЕДНИЦА У СРБИЈИ И СТРАНЕ ДИРЕКТНЕ ИНВЕСТИЦИЈЕ}

\begin{abstract}
Апстракт
Стране директне инвестииије као најзаступљенији облик међународног кретања капитала представљају значајан фактор развоја сваке економије. Због својих карактеристика у погледу утицаја на дугорочни економски развој, стране директне инвестищије нуде и могућност остваривања ииљева одрживог развоја. С обзиром да се ефекти страног капитала не манифестују на исти начин на свим нивоима у земљи домаћина, у раду се указује на значај страних директних инвестищија за јачање капацитета

${ }^{1}$ dragica.stojanovic@fmz.edu.rs

${ }^{2}$ biljana.ilic@fmz.edu.rs
\end{abstract}


локалних заједница у остваривању ичиљева одрживог развоја. У складу са тим, ичиљ рада је да кроз приказ кретања страних директних инвестиичја по општинама и градовима у Србији пружи корисне препоруке за побољшање пословне климе у привлачењу страних директних инвестиција у локалним заједницама. Полазећи од чињенице да су потребе локалних заједниия у Србији за привлачене страних директних инвестиција вишеструке, на крају рада указује се на најзначајније детерминанте земље домаћина које страни инвеститори узимају у обзир приликом доношења инвестиционих одлука и избора инвестиционе локације.

Кључне речи: Стране директне инвестиције (СДИ), одрживи развоји, локалне заједнице, детерминанте СДИ

\section{Introduction}

Foreign direct investments (FDI) are the main form of international capital movements. They occur when an investor located in one country, acquires the assets of another. The level of realized FDI in a country depends on many factors: geographic location, stability, environment, political and economic freedoms and risks, access to local and regional market, legal security, labor and institutional construction in the country (Ibreljić, 2011, p.114). FDI can be very useful when it comes to increasing per capita welfare of the citizens of a country.

However, the modern approach to foreign investment means that it primarily must be socially responsible and economically viable. Paralell with the development of science and technology, environmental concerns has become a main topic in 70 years of the last century. Today, people are becoming aware of the fact that environmental degradation is a global problem which needs to be urgently stopped (Čajka, Jovanović, 2015, pp.87-91). Since the question of the survival is of essential importance for the further prosperity of the entire planet, there is a need to build a special attitude towards the issue of sustainability. Sustainable development attends to create a better world, balancing economic, social and environmental factors in order to preserve the natural wealth for future generations. The main motto is to find paths of development, which will not endanger the environment (Malović et al., 2016, pp.171-175).

Local economic development is not just a concept, but it is also a process. Like any other process it consists of a number of steps and alternatives. Each step leads to the final goal, but with skipping or eliminating certain steps, whole process can be compromised. By including all activities or of certain elements in the process of economic development, it can be created own path of development (Bojovic, 2012). In accordance with the foregoing, as well as at the global economies level, local communities in Serbia are faced with the problem of economic development, which is reflected in the lack of capital. The complexity of the problems inherited local imposes the need defining new concept of sustainable development based on attracting FDI. Broadcast municipal bond of the municipality is cheaper than conventional loans from banks, which is the reason of attracting a large number of investors in order to implement concrete (Prokopović et 
al., 2016). In order with this, FDI requires special attention to development strategies at the community level, which recently acquire a completely new feature, feature of sustainability.

\section{FDI and goals of sustainable development of local communities in Serbia}

In today's global economy, foreign direct investment is the fastest way of region development of each country. FDI are the basic mechanism of the globalization of the world economy, assuming the role of key development factors of each country. For a state in which it invests, FDI mean new jobs, increase exports, and generally, the launch of economic growth and development. On the other hand, direct investment as a form of foreign investment, enabling the investor to acquire the right of ownership, control and management on the basis of invested capital. Large or smaller companies, that are striving to appear on many different world markets, can do this most easily by accomplishing production capacity with desired locations. In addition to the conquest of new markets, investing in other countries can also mean faster and cheaper supply of raw materials, electricity, transportation and easier access to free economic zones. The range of potential effects of FDI on the domestic economy is very wide. The effects are mostly positive and duplex, a key piece of evidence for this is in their very dynamic growth in recent decades. All countries participating in this process recorded significant economic growth, with of course a somewhat different situation last few years due to the global economic crisis has not bypassed this segment (Jevtic et al. 2011, pp. 228-235).

The term „Sustainable Development" was defined in 1989, and officially proclaimed by the Bergen Declaration of 1990, as development that dilled with the needs of the present generations, and possibility of future generations to achieve their own needs and to develop themselves. The interaction of environmental development and mutual coordination complementary with development and environmental policy, which respected of ecological systems are the essence of the concept. At the local level, sustainable development implies that local economic development supports economic and social life, using the talents and capabilities of the local population.

The sustainable development benefits from the development community is equally distributed to all social groups and ensure their longevity (http://lokalniodrzivirazvoj. webs.com/). In defining and implementing sustainable development, the most important step is to determine goals. These goals include a description of the actions that should be achieved to attain the desired look that is defined by a strategic future vision. The development complies with the requirements and limitations of nature, involves correlation of economic and environmental policy at all levels of society and its integration with modern international trends (Mihajlovic at. al., 2013).

Achieving goals requires a specific strategy for the local community, which is implemented through several stages ( Knežević et al. 2009, p. 116):

1) Analysis of the situation,

2) Defining strategic guidelines,

3) Defining objectives and indicators of sustainable development, 
4) Data collection and analysis, and

5) Defining and implementing actions.

Figure 1. Strategy of sustainable development - phase of process

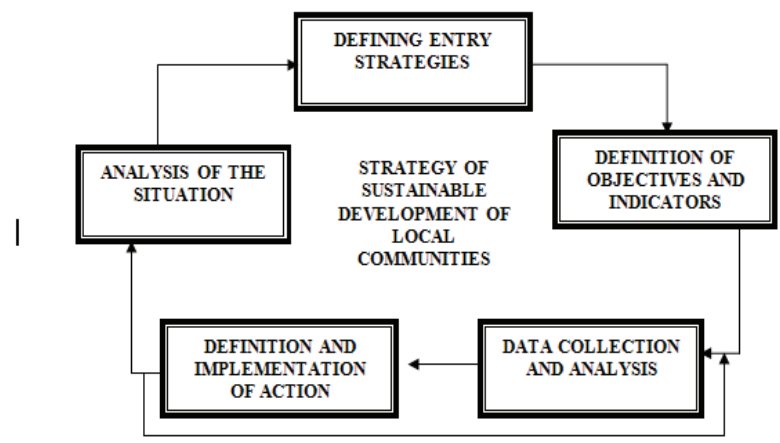

Source: Knezevic, Zivkovic, Puric, Janicijevic, 2009

Figure 2 represents the central phase of the strategy of sustainable development, the phases in which goals should be defined in order to be achieved, but also the mechanisms of monitoring their implementation. In oreder to define the strategy of the local community, it must be taken into account the fact that it is equally important to recognize problems, but also to recognize the opportunities and benefits for the local community. As the time and resources for strategy implementation are limited, it is inevitable to decide which aspects and to what extent, should be given priority when defining the objectives.

Access is shown in Figure 2. Figure 2 represents is there a problem or not, when it is making a decision that basis on the segment of sustainable development.

Figure 2. The process of setting priorities

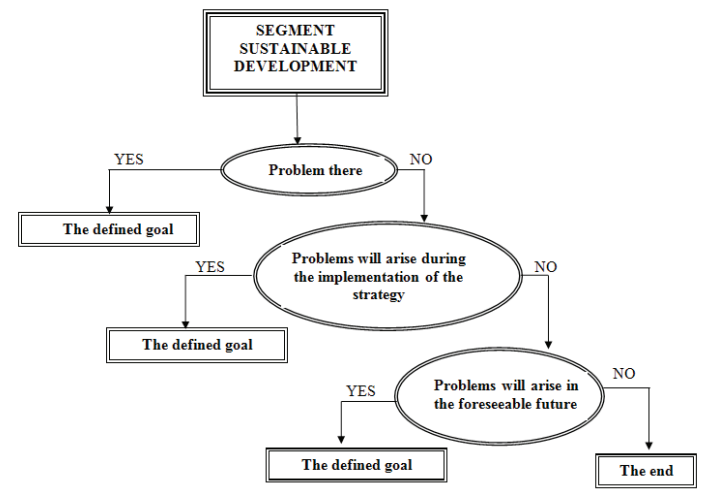

Source: Knezevic, Zivkovic, Puric, Janicijevic, 2009 
It can be seen that if there is a problem, it is necessary to define an appropriate objective of sustainable development to the local community and commit to work on its solution. If the problem still exists, or it will certainly occur in the time of period for which is strategy defined, it is necessary to define targets of problem that will prevent or mitigate its consequences. In the case when the problem is expected in the foreseeable future, it requires taking early actions to prevent developing of problem.

The advantages of this approach are that it is clear and easy to use. But it still does not have salvation of the problem that management has, in the case when it is necessary to decide which problem is priority.

These disadvantages can be solved by using the approach that takes into account the probability of occurrence of a problem (phenomena, events), its consequences and effects. Such approaches are define the character of a problem that has been identified in the situation analysis, defining it as a function of probability. The possibility of a problem or occurrence that is observed is called the probability, while the effect is presented as the consequences of their occurrence. The objectives of sustainable development should have some general characteristics: they must be clearly defined, measurable and achievable.

For example, the goal "How to be more attractive for foreign investment at the local level"; must be clearly defined, in terms of what kind of concrete investment are thoughts (for example Greenfield, or other). Therefore, methods for monitoring and measuring of the goals achievement must be clearly defined, too. But it is important for the goals to be realistic and achievable for a certain period of time.

\section{Dynamics of FDI income in Serbia}

One of the basic characteristics of the countries in transition, such as Serbia, is the low level of domestic capital accumulation, which stipulates the need for intensification of FDI inflows. After initial skepticism, the mid-nineties, the European countries in transition have begun to compete with each other in creating a more favorable investment environment to attract larger FDI. If it takes into account that the war of nineties imposed sanctions and the political turmoil, Serbia has consistently been shunned by foreign investors, as a destination for FDI. More intensive investment in Serbia started after 2000 (Stankov, Markov, Milošević, 2015, pp. 61-69).

The trends of FDI inflows in local communities in Serbia has significant variations, which is typical for developing countries, caused primarily because of to the implementation of the transition process and also because of the global economic and financial crisis (Table 1) (National Alliance for Local Economic Development (NALED).

From Table 1 it can be seen that Vrsac is the municipality with biggest foreign investments in the period from 2012 to 2016, in Serbia (662 million euros), while the city of Pancevo is on the second place with 526.5 million euro. The Titel is the municipality with the lowest FDI inflow, where it flowed only 200 thousand euros. From the same table it can be seen that FDI in Serbia is characterized by uneven distribution, which indicates the necessary analysis of the business environment in all municipalities of country. 
Table 1. FDI in Serbia, by municipalities and cities (2012-2016)

\begin{tabular}{|c|c|c|c|c|c|c|c|c|c|c|c|c|c|}
\hline Municipalities / city & 2012 & 2013 & 2014 & 2015 & 2016 & Total EUR & Municipalities / city & 2012 & 2013 & 2014 & 2015 & 2016 & Total EUR \\
\hline$A d a$ & & & & & 4641.600 & 4.641 .600 & Jagodina & 62500.000 & 4.200 .000 & & & & 66.700 .000 \\
\hline Nibunge & & & & & 66000000 & 6.600 .000 & Nuinda & & & & & 10000000 & 10.000 .000 \\
\hline Aleksinac & & 4.800 .000 & & & & 4.800 .000 & Knić & & 5.200 .000 & & & & 5.200 .000 \\
\hline posth & 27.000 .000 & & & 1.000 .000 & 470,0000000 & 498.000 .000 & Knjatevac & 1.900 .000 & & & & & 1.900 .000 \\
\hline$B a^{2}$ & & 3.000 .000 & & & 100000000 & 13.000 .000 & Koceljeva & & 1.800 .000 & & & & 1800.000 \\
\hline Backa Palanka & 2000000 & & & & 15.7000000 & 17.700 .000 & Koin & & & & & 2500000 & 2.500 .000 \\
\hline Bado Topola & & & & & 59000000 & 5.900 .000 & Kula & & & & & 15000000 & 15.000 .000 \\
\hline Basciseronac & & & & & 8000000 & 800.000 & Kursumlia & & 4.000 .000 & & & & 4.000 .000 \\
\hline Bactins & 6000000 & & & & 30000000 & 9.000 .000 & Lutani & & & 1.200 .000 & & & 1.200 .000 \\
\hline Bootin & & & & & 35967702 & 3.556 .702 & Wali 16005 & & 1.900 .000 & & & & 1.900 .000 \\
\hline Betej & & 1.000 .000 & 30.000 .000 & & & 31.000 .000 & Wionica & & & & & 700000 & 700.000 \\
\hline Belaciks & & 1.500 .000 & & & & 1.500 .000 & tis & $20,000.000$ & 3.500 .000 & & & $1.600 .000^{\circ}$ & 25.1000 .000 \\
\hline Beogys & & & & & 1140000000 & 114.000 .000 & Non Bebej & & & & & 700000 & 200.000 \\
\hline BAoypanNon Beogys & 450000000 & 4.600 .000 & & & 120.7000000 & 170.300 .000 & Non Sor & & & & & 4000000 & 4.000 .000 \\
\hline Beoprospalidua & & 30.000 .000 & & & 240000000 & 54.000 .000 & ottad & & & & & 15.666.157 & 15.666 .157 \\
\hline Geopradsarsivenac & & & 55.000 .000 & & 6000000 & 55.600 .000 & Pracoin & 7500.000 & & & & & 7.500 .000 \\
\hline Beograsstar Grad & & & & & 1520000000 & 152.000 .000 & Peánol & 10.000 .000 & & & & 124.4500000 & 134.450 .000 \\
\hline Beogys Surtin & & 40.000 .000 & & & & 40.000 .000 & Planolite & & & & & $19250000^{\circ}$ & 1.925 .000 \\
\hline Gominilinows & 2.500 .000 & & & & & 2500.000 & Ruma & 1600.000 & 4.000 .000 & & & 31.426 .765 & 37.026 .765 \\
\hline Can Kaleno & 9.300 .000 & & & & & $9,300.000$ & Sente & & 2.000 .000 & & & & 2000.000 \\
\hline Cay Kraguenac & 121.400 .000 & 2.000 .000 & & & 500000 & 123.900 .000 & Smedrevo & & 18.000 .000 & & & 1500000000 & 168.000 .000 \\
\hline an Lestione & 6000000 & & & & 5000000 & 6.500 .000 & srootran & & & & & 4500000 & 450.000 \\
\hline aty Nonsad & 151.000000 & 1.000 .000 & & & 450000000 & 197.000 .000 & Stemsin Karlovo & & & & & 80000000 & 8.000 .000 \\
\hline a) Panciono & 1000000 & & & & 82550000000 & 826.500 .000 & Stara Pasove & 5000.000 & & 18.500 .000 & & 99.5000000 & 123.000 .000 \\
\hline an Prot & 38000000 & & & & 8750,000 & 12.550 .000 & Subotca & & & & & 39.6000000 & 39.600 .000 \\
\hline CA SOMbor & 1500000 & & & & 737750000 & 75.275 .000 & Suroulica & 3000000 & & & & & 3.000 .000 \\
\hline CA Sirmsia utrovica & & 3.000 .000 & 20000.000 & & & 5.000 .000 & Silanack & & & & & 900000 & 900.000 \\
\hline CA Siemsia Mtroica & 20.0000000 & & & & 88.700 .000 & 108.7000 .000 & 810 & & & & & 88000000 & 8.800 .000 \\
\hline Car $\$ 3 b a c$ & & & & & 12000.000 & 12000.000 & Fitel & & & & & 200000 & 200.000 \\
\hline an Valeno & 20000000 & & & & & 20.000 .000 & Masolince & & & & & 700000 & 200.000 \\
\hline Coy Vanst & 20000000 & & & & 100000 & 29.1000 .000 & $\cos 3 x$ & 3000.000 & & & & 6590000000 & 662.000 .000 \\
\hline Car catar & & & & 10.000 .000 & & 10.000 .000 & Cuspria & & 10.000 .000 & & & & 10.000 .000 \\
\hline $\ln \delta_{i}$ & 16.0000000 & 1.500 .000 & $54,000.000$ & & 1130000000 & 184.500 .000 & Zrengain & 10.000 .000 & & & & 88.100 .000 & 96.1000 .000 \\
\hline
\end{tabular}

Source: National Alliance for Local Economic Development (NALED)

\section{Determinants for attracting of FDI in Serbia}

Based on the analysis of FDI in Serbia, but also taking the fact that the competition among developing countries in attracting FDI is large, it can be concluded that basic economic conditions for attracting investment is not enough to encourage foreign investors to come in Serbia. Starting from the fact that the interest of foreign investors has a certain risk, the areas that investors avoid are unstable economy, national currency, social unrest, inconsistent of monetary and fiscal policies (Kula, 1998, p.19).

Therefore, without a favorable business environment, Serbia will not have foreign investment, especially when it comes to Greenfield investments. Countries that its overall policy environment is to ensure stable conditions for the smooth and profitable operation will certainly faster and easier for attracting FDI, than the countries where the investment environment is not sufficiently favorable. (Mihailović, Simonović, 2016, p.58). 
Table 2. Determinants of SDI host country

\begin{tabular}{|c|c|c|}
\hline Determinants of the host country & $\begin{array}{l}\text { Type of FDI to } \\
\text { the investor's } \\
\text { motives }\end{array}$ & $\begin{array}{l}\text { The most important } \\
\text { economic determinants } \\
\text { for investing capital }\end{array}$ \\
\hline $\begin{array}{l}\text { I. Political framework } \\
\text { - economic, political and social stability } \\
\text { - regulations regarding entry and operation in it } \\
\text { - standards of treatment in the country of affiliation } \\
\text { - Policies functioning and structure of the market } \\
\text { - international agreements on foreign investments } \\
\text { - privatization policy } \\
\text { - trade policy and compliance with the policy of } \\
\text { foreign investment } \\
\text { - tax policy }\end{array}$ & $\begin{array}{l}\text { The search for } \\
\text { market }\end{array}$ & $\begin{array}{l}\text { - market size and per } \\
\text { capita GDP } \\
\text { - market growth } \\
\text { - access to regional } \\
\text { markets } \\
\text { - the specific tastes of } \\
\text { consumers of the earth } \\
\text { - market structure }\end{array}$ \\
\hline II. Economic framework & $\begin{array}{l}\text { The search for } \\
\text { resources }\end{array}$ & $\begin{array}{l}\text { - raw material } \\
\text { - low labor cost of } \\
\text { unskilled labor } \\
\text { - professional work } \\
\text { - technological, } \\
\text { innovative and other } \\
\text { acquired resources } \\
\text { - physical infrastructure }\end{array}$ \\
\hline $\begin{array}{l}\text { III. Easing investment and business } \\
\text { - Investment promotion } \\
\text { - Incentives for investors } \\
\text { - reduction of administrative barriers } \\
\text { - services following the investments }\end{array}$ & $\begin{array}{l}\text { The search for } \\
\text { efficiency }\end{array}$ & $\begin{array}{l}\text { - cost of resources and } \\
\text { assets } \\
\text { - other input costs } \\
\text { (transport and } \\
\text { communications costs } \\
\text { to / from and within the } \\
\text { host country, the cost of } \\
\text { other intermediate } \\
\text { products) } \\
\text { - membership in regional } \\
\text { integration applicable to } \\
\text { the establishment of } \\
\text { regional corporate } \\
\text { networks }\end{array}$ \\
\hline
\end{tabular}

Source: Marjanović, 2011.

According to this, the essential determinants of the host country for foreign investors include political and economic framework of the country as well as measures to facilitate investment and business. The importance of individual determinants depends on the motives of the implementation of FDI. Table 2 shows the determinants of FDI in host country (Marjanović, 2011, pp. 215-220). The decision for investing outside the country, imposes the need for a detailed analysis of the business environment of the host country. Detailed analysis of the business environment involves primarily an analysis of the economic environment of the host country (the size and structure of the population, the analysis of the level and mode of distribution of income and wealth). 
Apart from analyzing of the economic environment it is necessary to analyze the cultural environment or its individual elements (language, education, religion, aesthetics, habits and customs, etc.).

Special attention must be paid to the analysis of the legal and political environment, when a country is going to make investment decisions. So it can be concluded that foreign investors are following the political situation, laws, procedures and regulations in potential host countries, when they are making decisions of investment (Sinanagić et al. 2013, pp.107-124). This is a very important, because foreign investors can see the potential risks on that way. The economic development, even without the knowledge of the concept of sustainable development is impossible without taking into account other elements of social development. That fact is based on survey of investors conducted in Serbia in 2008, in which they are showing these characteristics (Bojovic, 2012) :

- the quality of the human resources,

- political stability,

- quality and accessibility of infrastructure,

- quality of life and

- $\quad$ ease administrative procedures.

Undeveloped nations - Serbia and its working class - However, workers based in undeveloped nations cannot be the reason behind the stagnation of, or decrease in workers' wages from developed countries. On the contrary, the self-expanding logic of capital in its hunger for profits is the main reason for the international differentiation of the working class. This differentiation is expressed in the deskilling of workers, in the differentiation of the labor process (and patterns of production and reproduction of labor power), damage to the living labor fund due to super-exploitation, the establishment of international wage differentials etc. Capital prevents the international unity of working classes by dividing them, "taking advantage of areas of uneven development and amplifying existing schisms"(Palloix, 1977, p. 123).

Opposite investment promotion, which applies only to placement of the benefits and conditions of investment in a particular municipality, attracting investments is a broad term that includes improving the local business climate and infrastructure, a variety of incentives and benefits to investors (price reduction for lease of land, exemption from taxes, etc.). There are several political statements regarding FDIs circulating in the Serbian public sphere. The first one stubbornly repeats that foreign investors come to Serbia because of Serbia, its people and their knowledge. This 'argument' mainly appears in politicians' discourses, as well as among the media and press. The second statement asserts that FDIs bring technological progress by creating positive spillover effects. The term spillover effect refers to the indirect influence of FDIs on the host country, where statistical associations between transnational and productivity improvements in local domestic firms are interpreted as resulting from technology transfers between foreign affiliates and domestic firms. The dominance of labor intensive production in Serbia hardly confirms this to date. The third statement asserts that FDIs positively affect the national market by boosting competition. However, it is well known that foreign companies in Serbia are incorporated in networks maintaining a monopoly, and that they import almost all of their raw materials and intermediary inputs from abroad. In doing so, they directly eliminate domestic suppliers, thus exhausting and petrifying the whole economy (Radenkovic, 2016). 
Regimens to the fact that Serbia is characterized by uneven development of its regions, it is necessary to pay more attention to the work force, i.e. working class in less developed regions and in less developed Serbian municipalities and cities. Human resources are irreplaceable. It is important for Serbia not to allow its young people leave the country, and therefore it is necessary to take urgent measures to prevent the brain drain from Serbia abroad. However, that is another question, but the fact is that country can not be able to attract foreign capital without its own intelligence.

\section{Conclusion}

The activities of a municipality for FDI are determined by the dynamism and competitiveness of its business sector. Therefore, the development of entrepreneurial spirit is also a factor for attracting FDI and for achieving the goals of sustainable development of local communities. Analysis of FDI by municipalities and cities in Serbia indicate a growing movement in the period. However, despite these facts, the performed analysis indicates the solution to the problem of risk that foreign investors stand out as significant limitations when making investment decisions. As a candidate for EU membership, the prerequisites for attracting foreign investors in Serbia are: the establishment of political and macroeconomic stability, trade liberalization and solving the problem of corruption..

Therefore, the continued economic, institutional and legislative reforms throughout the territory with the strengthening of infrastructure networks in local communities enable the creation of a favorable investment climate. The fact that the capital is in the process of globalization one of the most mobile factor that can speed up the economic development of the country in which the funds invest, but also a factor for the creation of a favorable institutional environment, it is a long term process that needs to maximize the positive effects and minimize the negative effects of foreign investment.

The analysis made in this paper indicates that Serbia is gradually becoming an attractive investment destination, thanks to its many advantages. Finally, in order for Serbia to create the conditions for long-term economic and sustainable development of local communities, it is necessary to take advantage of the globalization process benefits and on that way try to attract the inflow of FDI in the host country.

\section{References}

Bojović, J. (2012). Local economic development, Bookfor practice, available at:http:// www.naledserbia.org/documents/LED-Guidebook2.pdf, accessed: 20.02.2017

Ibreljić, I., Nuhanović, S. (2011). Strane direktne investicije u funkciji ekonomske transformacije ekonomske strukture zemalja jugoistočne Evrope, Zbornik radova sa druge međunarodne naučne konferencije Ekonomija integracija - Izazovi i perspektive integracija zemalja jugoistočne Evrope, Tuzla: Ekonomski fakultet.

Jevtić, P., Mihajlović - Stošić, LJ., Skok - Merkac, M. (2011). Uticaj investicija na privredni razvoj, Zbornik radova "EDASOL 2011 - Economic development and Standard of living”. Banja Luka. 
Knežević D., Živković N., Purić A., Janićijević I. (2009). Ciljevi održivog razvoja lokalne zjednice, Zbornik radova sa IV Festivala kvaliteta, Kragujevac.

Kula, E. (1998). History of Environmental Economic Thought. London \& New York: Routledge.

Malović, M., Matić, M., Ilić, B. (2016). Prirodni resursi i društveno odgovorno poslovanje preduzeća sagledavanjem klimatskih promena. Ecologica 23 (4).

Marjanović, D. (2011). Competitiveness of the economy in attracting foreign direct investment. I International Symposium Engineering Management And Competitiveness (EMC 2011).

Mihailović, B., Simonović, Z. (2016), Strateško planiranje održivog razvoja poljoprivrede i ruralnih područja u Srbiji, Institut za ekonomiku poljoprivrede, Beograd.

Mihajlović D., Ilić B., Simonović Z. (2013), Razvoj održive ekonomije prirodnih resursa u skladu sa ekološkim zahtevima, Ekonomika, 59(4), 10-22.

National Alliance for Local Economic Development (NALED) i Republički zavod za statistiku. Internet: http://www.naledserbia.org/investments/index/ Baza+investicija

accessed: 15.3.2017.

Održivi razvoj kao program akcije za lokalne zajednice, Internet: http:// lokalniodrzivirazvoj.webs.com/, accessed: 16.3.2017.

Palloix, C. (1977). Svjetska kapitalistička privreda i multinacionalne kompanije, Stvarnost, Zagreb.

Prokopović, T. B., Mladenović, M. Z., \& Mihajlović, M. R. (2016). Municipalne obveznice lokalne samouprave. Ekonomika, 62(4), 175-182.

Radenkovic, I. (2016). Foreign Direct Investment in Serbia, Rosa Luxemburg Stiftung Southeast Europe, Standard 2, Beograd.

Sinanagić, M., Čivić, B., Kamarić, A (2013). Pokretački faktori i determinante stranog direktnog investiranja u Bosni i Hercegovini, Tranzicija, 15 (31).

Stankov, B., Markov J., Milošević, I (2015). FDI by incoming activities and investment incentives in Bulgariaand Serbia, Management 77 (3).

Čajka, Z., Jovanović, L.. (2015). Principi održivosti i održivi proizvodi, Ecologica, 77 (4). 